\title{
Dye-Coupling in Taste Buds in the Mudpuppy, Necturus maculosus
}

\author{
Jian Yang and Stephen D. Roper \\ Department of Anatomy and Neurobiology, Colorado State University, Fort Collins, Colorado 80523
}

\begin{abstract}
Electrical coupling in taste buds and in non-taste lingual epithelium in the mudpuppy was examined by injecting cells with a fluorescent dye, Lucifer yellow. Lucifer yellow coupling has been shown to indicate the presence of electrical junctions between cells. Lucifer yellow-filled taste cells usually have an elongate shape. Cells were an average of 111 $\mu \mathrm{m}$ long and were $13 \mu \mathrm{m}$ in diameter at the widest region (nucleus). In taste buds, from a sample of 105 impalements we detected Lucifer yellow coupling in 21 cases: dye-coupled pairs of cells were observed in 17 cases, and trios of cells in 4 cases. Larger subsets of coupled cells $(>3)$ were not observed. Dye-coupled cells were usually equally intensely stained. In non-taste epithellum, we examined dyecoupling in the superficial and basal layers. Extensive Lucifer yellow coupling was found in the basal layer (15/15 cases). The number of cells coupled to the dye-injected cell varied from 3 to 5 . In the superficial epithelium, dye-coupling was rare (1/45 cases). No dye-coupling was observed between epithelial cells and taste cells at the taste pore region. We conclude that strong electrical coupling in groups of 23 cells occurs in the mudpuppy taste buds. Coupling may occur selectively between identical types of taste cells (dark, light, etc.), but this remains to be determined. Electrical coupling also exists among basal epithelial cells but not in the superficial epithelial layers.
\end{abstract}

The unit organization of vertebrate taste buds is not well understood. Although it is possible that the unit of organization is the single receptor cell, it is also possible that small groups of electrically coupled taste cells function in a coordinated fashion. Thus, chemical stimuli may sclectivcly affect groups of coupled cells rather than individual taste receptor cells. We have tested this possibility by injecting taste cells with Lucifer yellow and examining dye-coupling between the cells, the existence of which might suggest the presence of specific subpopulations within the vertebrate taste bud.

The fluorescence dye Lucifer yellow crosses gap junctions in a number of epithelial and neural tissues (Kater and Galvin, 1978; Stewart, 1978; Glantz and Kirk, 1980; MacVicar and Dudek, 1980; Spencer and Satterlie, 1980; Gutnick and Prince, 1981; Schuetze and Goodenough, 1982). This dye-coupling implies the existence of low-resistance pathways between cells (electrical coupling). Dye-coupling has recently been demon-

Received Nov. 3, 1986; revised Apr. 27, 1987; accepted Apr. 30, 1987.

This work was supported in part by NIH Grants NS 24007, AG 06557, and NS 20486. We would like to thank Drs. Robert E. Lee and Peter Guthrie for their technical assistance.

Correspondence should be addressed to Dr. Stephen D. Roper at the above address.

Copyright (C) 1987 Society for Neuroscience $0270-6474 / 87 / 113561-05 \$ 02.00 / 0$ strated among taste cells and epithelial cells in catfish taste buds (Teeter, 1985). Electrophysiological data suggest that electrical coupling may exist between surface epithelial cells and also between taste cells in the mudpuppy, Necturus maculosus (West and Bernard, 1978), but the extent of coupling among these cells has not been determined in detail. We have used intracellular staining with Lucifer yellow to investigate the possibility of dyecoupling among taste cells and/or epithelial cells in the mudpuppy. Dye-coupling was frequently observed between taste cells and also between basal epithelial cells, but surface epithelial cells were rarely dye-coupled to each other or to other types of cells.

\section{Materials and Methods}

Lingual epithelium from the mudpuppy was dissected as previously described (Roper, 1983) and maintained in vitro at $4^{\circ} \mathrm{C}$ for up to $3 \mathrm{~d}$. Experiments were performed with preparations incubated with an amphibian physiological solution $\left(112 \mathrm{~mm} \mathrm{NaCl}, 8 \mathrm{~mm} \mathrm{CaCl}_{2}, 2 \mathrm{mM} \mathrm{KCl}\right.$, $5 \mathrm{~mm}$ HEPES buffered to $\mathrm{pH} 7.2$ with $\mathrm{NaOH}$ ) at room temperature. Cells were impaled intracellularly and injected with fluorescent dyes under direct visual control using Nomarski interference contrast optics. For intracellular recording and dye injection, glass electrodes were filled with either a $4 \%$ solution of the lithium salt of Lucifer yellow CH (Sigma) in $0.1 \mathrm{M} \mathrm{LiCl}$ or a solution of $1.5 \%$ Lucifer yellow and $30 \%$ rhodaminelabeled dextran (MW: 10,000; Molecular Probes) in 25 mM HEPES buffer ( $\mathrm{pH} 7.0$ ). These electrodes had resistances of 120-250 M $\Omega$ after the tips were intentionally broken to facilitate dye injection. Lucifer yellow or a combination of Lucifer yellow and rhodamine-dextran was injected iontophoretically by passing either $1.5-2.5 \mathrm{nA}, 900 \mathrm{msec}$ negative current pulses at $1 \mathrm{~Hz}$ for $45 \mathrm{sec}$ to $3 \mathrm{~min}$ or $2 \mathrm{nA}$ negative DC currents for 2-3 min. Action potentials in taste cells (Roper, 1983) and resting membrane potentials in taste and epithelial cells were monitored continuously during the dye injection to confirm the target site and also so that dye injection could be terminated before or immediately after the penetration was lost. After injection, the tissue remained in the recording chamber for $1 / 4-7 \mathrm{hr}$ and was then fixed in $2 \%$ paraformaldehyde in either $0.1 \mathrm{M}$ sodium phosphate or $0.1 \mathrm{M}$ cacodylate buffer ( $\mathrm{pH} 7.4$ ) for 2-24 hr. To observe dye-filled cells, the tissue was sectioned at $60 \mu \mathrm{m}$ thickness on a cryostat. Whole-mount tissues or sections were examined and photographed with Zeiss or Nikon epifluorescence microscopy and appropriate filters.

\section{Results}

\section{Morphology of taste cells}

A total of 105 taste cells in as many taste buds was successfully injected with Lucifer yellow. In all instances, the presence of action potentials was monitored before, during, and after Lucifer yellow injection. Action potentials varied in peak amplitude from 20 to $55 \mathrm{mV}$ (with an average of $35 \mathrm{mV}$ ) before dye injection. Current injection was usually terminated before the action potential amplitude fell to one-third of its initial height. Lucifer yellow-stained taste cells usually had an elongated shape with one apical and one basal process (Fig. $1 A$ ). In some cases $(<10 \%)$, the apical process or the basal process divided into 2 smaller processes (Fig. $1 B$ ). Cells were an average of $111 \pm 18$ 
$( \pm \mathrm{SD}, n=25) \mu \mathrm{m}$ long and were $13 \pm 2.0( \pm \mathrm{SD}, n=23) \mu \mathrm{m}$ in diameter at the nuclear region. The basal process usually terminated in a number of finely branched, fingerlike projections that extended to the base of the taste bud (Fig. $1 C$ ). The apical processes extended to the taste pore (Fig. 1, $A, B$ ). Usually, the diameters of the apical processes were larger than those of the basal processes. This shape is similar to that revealed by histological and ultrastructural studies on taste cells in the mudpuppy (Farbman and Yonkers, 1971; Delay and Roper, unpublished observations).

\section{Dye-coupling in taste buds}

Dye-coupling between taste cells was observed in 21 instances. In 17 cases, 2 cells were stained with Lucifer yellow after a single intracellular injection. In 4 cases, 3 cells were stained (Fig. 2, $A, B)$. Larger subsets of coupled cells ( $>3$ ) were not observed. Dye-coupled pairs (or trios) of taste cells usually appeared to be equally stained, indicating that the coupling was strong. Cells in the pairs (or trios) also had quite similar shapes, and their apical processes were usually bigger and flatter than those of the single taste cells (Figs. $2 B ; 3, A, B$ ). Since the average number of cells in the mudpuppy taste bud is 100 , this means that approximately $20 \%$ of the cells are dye-coupled (therefore, electrically coupled) and in groups of 2 or 3 cells. Although the sites of coupling could not be determined with certainty, we observed close apposition between cell bodies and/or apical processes.

In one set of control experiments, Lucifer yellow-filled microelectrodes were inserted into taste buds without impaling cells, and Lucifer yellow was injected extracellularly with large currents (2-3 nA) for extended periods $(5-10 \mathrm{~min})$. We did not find any cells stained after this procedure. This is in agreement with the results of others, who have indicated that Lucifer yellow is not taken up by extracellular injection (Stewart, 1978; MacVicar and Dudek, 1980; Gutnick and Prince, 1981).

In a second series of experiments aimed at controlling possible microelectrode damage and subsequent nonselective leakage of Lucifer yellow into injured cells (which might produce artifactual dye-coupling), as well as to identify the dye-injected taste cell from the adjacent coupled ones, we developed a doublelabeling technique: 2 fluorescent dyes, rhodamine-dextran (which has a molecular weight of 10,000 daltons and, therefore, cannot pass through intercellular pathways) and Lucifer yellow were iontophoretically injected into single taste cells simultaneously. The extent of diffusion of each of the 2 dyes was then examined separately with fluorescence microscopy by using different sets of filters. As shown in Figure 3, where Lucifer yellow coupling was observed between taste cells (Fig. $3 A$ ), rhodamine-dextran always remained in the dye-injected cell (Fig. $3 B$ ). This indicates that Lucifer yellow coupling is not produced by cell damage or cell membrane leakage and is truly a consequence of specialized intercellular junctions.

\section{Dye-coupling among non-taste epithelial cells}

Lucifer yellow was also injected into superficial surface epithelial (SE) cells and basal epithelial (BE) cells to determine whether there was dye-coupling among epithelial cells or between epithelial and taste cells. In order to impale basal epithelial cells, the lingual epithelium was pinned upside down (serosal surface up) in the recording chamber and incubated with collagenase (CLS III)-albumin solution ( $2 \mathrm{mg}$ each/ml in APS) for $1 \mathrm{hr}$. After this treatment, the connective tissue on the serosal side could be greatly peeled off with care, and it was then possible
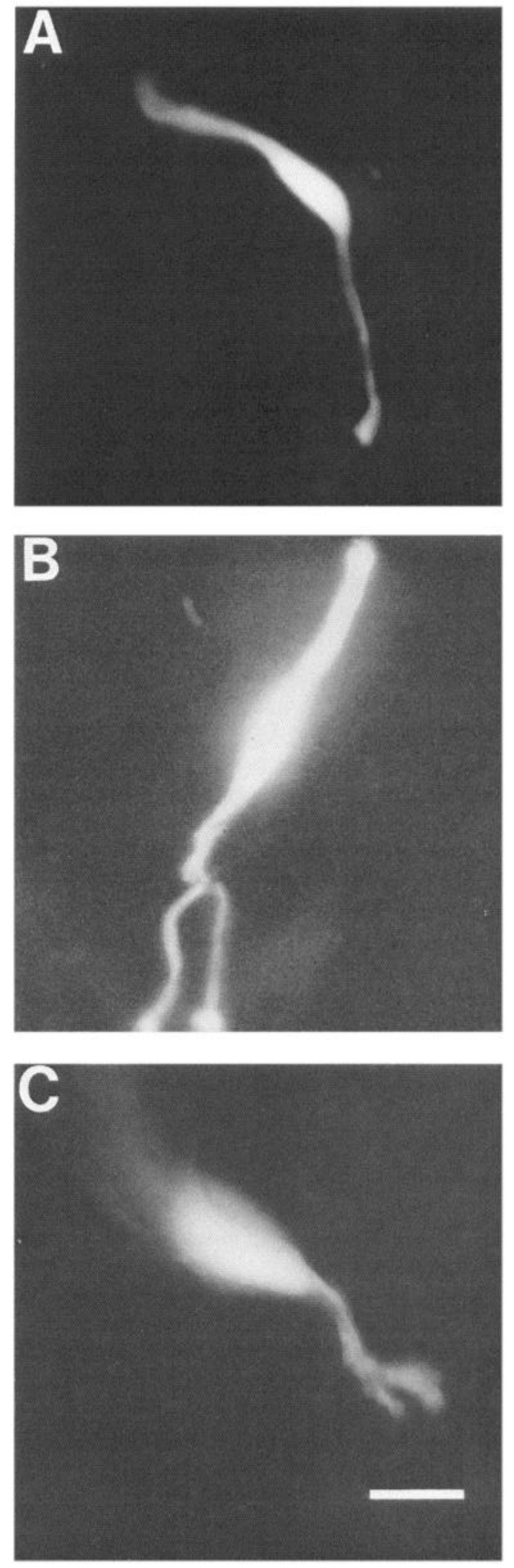

Figure 1. Morphology of individual taste cells in the mudpuppy. Lucifer yellow was iontophoretically injected into a single taste cell. Thick $(60 \mu \mathrm{m})$ sections cut transversely through taste buds were photographed with fluorescence microscopy. $A$, An elongated taste cell with one apical process and one basal process. This was the most common morphology observed. $B$, Another taste cell with one apical process and two basal processes. $C$, Micrograph of another taste cell, showing the fingerlike projections of the basal process. Note that the apical process is out of the plane of focus. Calibration bar: $A$ and $B, 30 \mu \mathrm{m} ; C, 15 \mu \mathrm{m}$. 

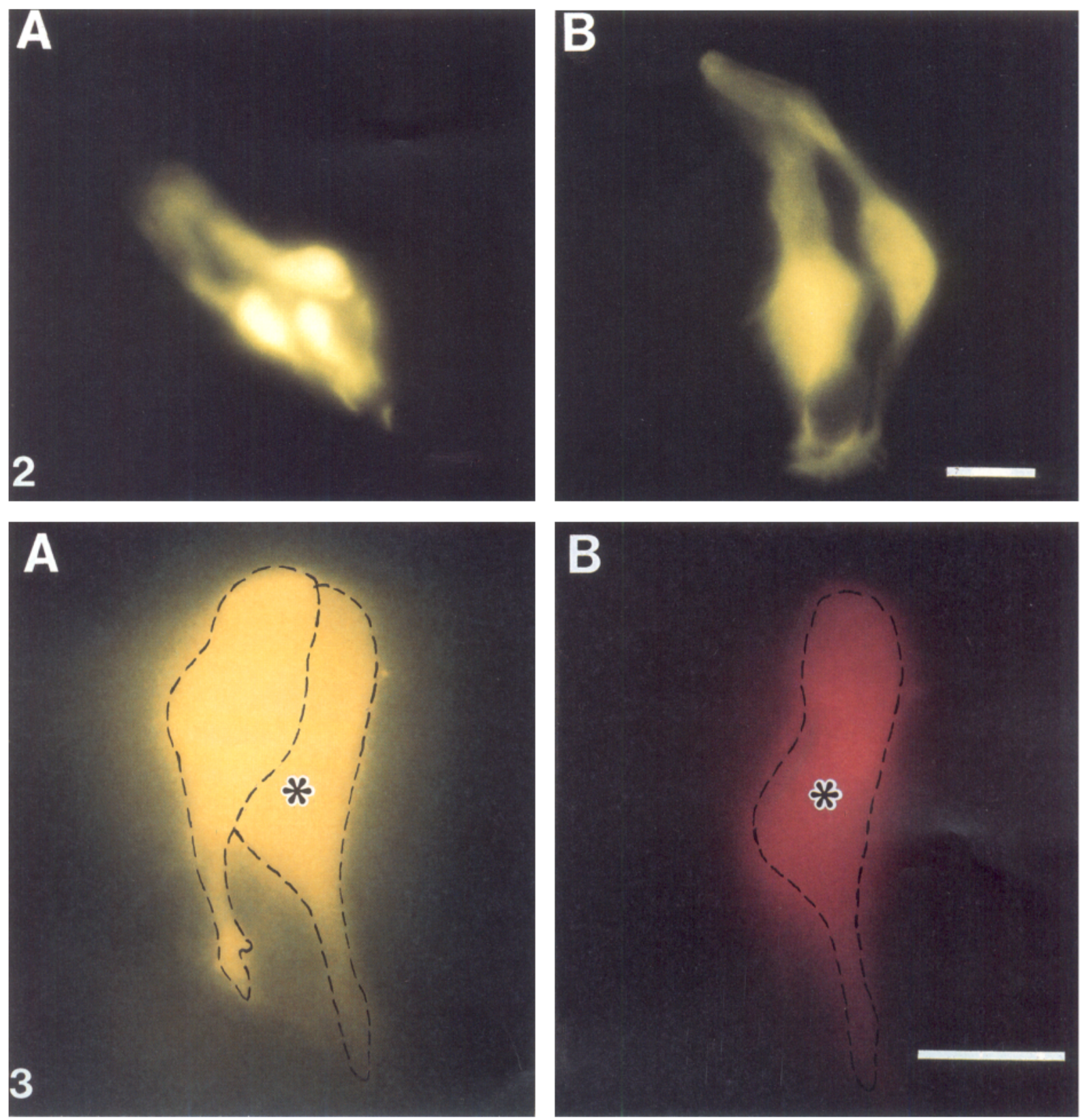

Figure 2. Dye-coupling of taste cells in the mudpuppy. Two examples are shown in which a single taste cell was injected intracellularly with Lucifer yellow and more than one cell was stained with the fluorescent dye. As in Figure 1, thick sections were viewed and photographed. $A$, Three taste cells contain Lucifer yellow. The apical processes are out of the plane of focus. $B$, Another example of 3 dye-coupled taste cells. Two of the taste cells are superimposed in this micrograph. The apical processes lay close together at the taste pore. Calibration bar: $A, 32 \mu \mathrm{m} ; B, 20 \mu \mathrm{m}$.

Figure 3. Lucifer yellow and rhodamine-dextran double labeling of taste cells. The above 2 dyes were injected into the same taste cell simultaneously. Thick sections through the taste buds were photographed with fluorescence microscopy. $A$, Lucifer yellow coupling between 2 taste cells, photographed with blue excitation. The coupled cell was partially superimposed upon the impaled cell $(\cdot)$. The profiles of the cells are outlined by dashed lines. $B$, Same field of view photographed with green excitation. Rhodamine-dextran remains in the dye-injected cell (*). Calibration bar, $20 \mu \mathrm{m}$.

to impale BE cells intracellularly. Resting potentials of SE and $\mathrm{BE}$ cells varied from -10 to $-45 \mathrm{mV}$.

Forty-five SE cells were injected with Lucifer yellow. Sixteen of these cells were immediately adjacent to taste pores. Only in one case were SE cells dye-coupled, and this coupling was very weak. No SE cells were coupled to taste cells (Fig. 4A).

In another series, $15 \mathrm{BE}$ cells were successfully injected with Lucifer yellow, and in all cases, adjacent cells were dye-coupled to the impaled cell. The number of cells coupled to the dyeinjected cell varied from 3 to 5 . Invariably, the impaled cells were brightly stained and the adjacent dye-coupled cells were less intensely stained (Fig. 4C). Dye-coupling among BE cells is unlikely to be an effect produced by the enzymatic digestion procedure: we found no dye-coupling between SE cells in tissues that had been subjected to the same treatment.

\section{Discussion}

Our results with Lucifer yellow demonstrate that about $20 \%$ of taste cells in the mudpuppy are coupled to 1 or 2 other taste cells under the conditions of our experiments (Fig. 2, $A, B$ ). 

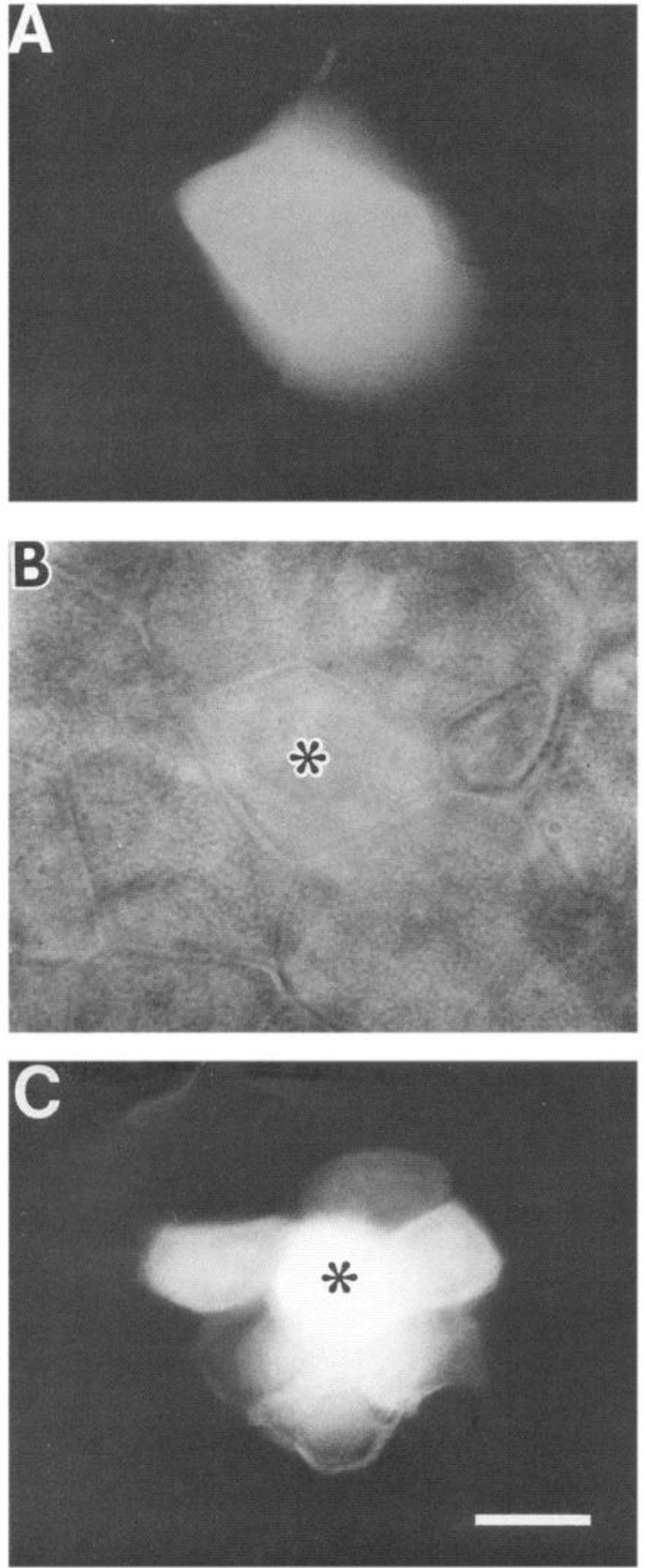

Figure 4. Absence of dye-coupling between surface epithelial cells and extensive dye-coupling among basal epithelial cells. Flat, whole-mounted tissues were viewed and photographed with fluorescence microscopy. $A$, Surface epithelial cell injected with Lucifer yellow. No dye-coupling with adjacent cells is visible. $B$, Bright-field micrograph of the tissue containing the above surface epithelial cell $(*)$. $C$, Basal epithelial cell $(\cdot)$ injected with Lucifer yellow. Dye-coupling to 6 other adjacent basal epithelial cells can be seen. Calibration bar, $20 \mu \mathrm{m}$.

Non-taste, BE cells are extensively coupled to their adjacent cells (Fig. $4 C$ ). SE cells, on the other hand, are only infrequently dye-coupled. Dye-coupling indicates the presence of electrical coupling, especially strong coupling, in many cases (Kater and Galvin, 1978; Glantz and Kirk, 1980; Spencer and Satterlie, 1980; Gutnick and Prince, 1981). Therefore, our results suggest that some taste cells in the mudpuppy are strongly electrically coupled, forming subunits of 2 or 3 cells. Weak electrical coupling, however, is not always revealed with Lucifer yellow dye transfer (Audesirk et al., 1982; Murphy et al., 1983). Hence, our estimate of the extent of electrical coupling is a conservative one.

There are at least 2 different types of taste cells (light and dark) in mudpuppy taste buds (Farbman and Yonkers, 1971; Delay and Roper, unpublished observations), as in other vertebrates (e.g., Kinnamon et al., 1985). It will be of interest to determine whether dye-coupling occurs selectively between specific cell types.

The absence of dye-coupling among lingual SE cells in the mudpuppy was somewhat unexpected. Lingual SE cells have been shown to be electrically coupled in Necturus (West and Bernard, 1978), and dye-coupling was found between SE cells in catfish taste buds (Teeter, 1985). One explanation of the absence of Lucifer yellow dye-coupling between SE cells in the mudpuppy is that they are only weakly electrically coupled. Indeed, electrical coupling between the SE cells in this species is very weak, with coupling ratios averaging about 0.1 (West and Bernard, 1978). Murphy et al. (1983) demonstrated in an invertebrate preparation that dye-coupling was well correlated with the strength of electrical coupling, and virtually no dyecoupling was observed in neuronal pairs with electrical coupling coefficients less than 0.50 . Loss of gap junctional coupling during cell differentiation has been shown to occur in a number of tissues (Fujisawa et al., 1976; Spitzer, 1982; Armstrong et al., 1983). It may be that intercellular communication in stratified epithelial cells in the tongue of the mudpuppy declines during development and differentiation from stratum basale (BE cells) to more superficial (SE cells) layers.

There is yet no unequivocal ultrastructural correlation for dye- or electrical coupling between taste cells or epithelial cells in the mudpuppy tongue. Tight junctions (zonula occludentes) have been observed in lingual epithelium and taste cells in Necturus (Farbman and Yonkers, 1971; Cummings et al., 1987), but most investigators do not attribute electrical or dye-coupling to these intercellular specializations. Gap junctions have been observed between cells in rat taste buds (Akisaka and Oda, 1978), and it is likely that a close inspection of taste buds in the mudpuppy will reveal similar features.

There are many factors, such as intracellular $\mathrm{pH}$ and transjunctional potential, that significantly affect intercellular junctional conductances in other tissues (Spray et al., 1979, 1981; Turin and Warner, 1980; White et al., 1982). It is possible that alterations in junctional conductance may influence the unit organization within taste buds and alter taste transduction. However, the functional significance of electrical coupling among taste cells and its possible modulation by environmental factors remain to be determined.

\section{References}

Akisaka, T., and M. Oda (1978) Taste buds in the vallate papilla of the rat studied with freeze-fracture preparation. Arch. Histol. Jpn. 41: 87-98.

Armstrong, D. L., L. Turin, and A. E. Warner (1983) Muscle activity and the loss of electrical coupling between striated muscle cells in Xenopus embryos. J. Neurosci. 3: 1414-1421.

Audesirk, G., T. Audesirk, and P. Bowsher (1982) Variability and frequent failure of Lucifer yellow to pass between two electrically coupled neurons in Lymnaca stafnalis. J. Neurobiol. 13: 360-375.

Cummings, T., R. J. Delay, and S. D. Roper (1987) Ultrastructure of 
apical specializations of taste cells in the mudpuppy, Necturus maculosus. J. Comp. Neurol. 261: 604-615.

Farbman, A. J., and J. D. Yonkers (1971) Fine structure of the taste bud in the mudpuppy, Necturus maculosus. Am. J. Anat. 131: 353370.

Fujisawa, H., H. Morioka, K. Watanabe, and H. Nakamura (1976) A decay of gap junctions in association with cell differentiation of neural retina in chick embryonic development. J. Cell Sci. 22: 585-596.

Glantz, R. M., and M. D. Kirk (1980) Intercellular dye migration and electrotonic coupling within neuronal networks of the crayfish brain. J. Comp. Physiol. 140: 121-133.

Gutnick, M. J., and D. A. Prince (1981) Dye coupling and possible electrotonic coupling in the guinea pig neocortical slice. Science 211 : $67-70$.

Kater, S. B., and N. J. Galvin (1978) Physiological and morphological evidence for coupling in mouse salivary gland acinar cells. J. Cell Biol. 79: 20-26.

Kinnamon, J. C., B. J. Taylor, R. J. Delay, and S. D. Roper (1985) Ultrastructure of mouse vallate taste buds. I. Taste cells and their associated synapses. J. Comp. Neurol. 235: 48-60.

MacVicar, B. A., and F. E. Dudek (1980) Dye-coupling betwecn $\mathrm{CA}_{3}$ pyramidal cells in slices of rat hippocampus. Brain Res. 196: 494497.

Murphy, A. D., R. D. Hadley, and S. B. Kater (1983) Axotomyinduced parallel increases in electrical and dye coupling between identified neurons of Helisoma. J. Neurosci. 3: 1422-1429.

Roper, S. D. (1983) Regenerative impulses in taste cells. Science 220: $1311-1312$.

Schuetze, S. M., and D. A. Goodenough (1982) Dye transfer between cells of the embryonic chick lens becomes less sensitive to $\mathrm{CO}_{2}$ treatment with development. J. Cell Biol. 92: 694-705.

Spencer, A. N., and R. A. Satterlie (1980) Electrical and dye-coupling in an indentified group of neurons in a coelenterate. J. Neurobiol. 11 : 13-19.

Spitzer, N. C. (1982) Voltage- and stage-dependent uncoupling of Rohon-Beard neurons during embryonic development of Xenopus tadpoles. J. Physiol. (Lond.) 330: 145-162.

Spray, D. C., A. L. Harris, and M. V. L. Bennett (1979) Voltage dependence of junctional conductance in early amphibian embryo. Science 204: 432-434.

Spray, D. C., A. L. Harris, and M. V. L. Bennett (1981) Gap junctional conductance is a simple and sensitive function of intracellular $\mathrm{pH}$. Science 211: 712-715.

Stewart, W. W. (1978) Functional connections between cells as revealed by dye-coupling with a highly fluorescent naphthalimide tracer. Cell 14: 741-759.

Teeter, J. (1985) Dye-coupling in catfish taste buds. In Proc. 19th Jpn. Symp. Taste and Smell, S. Kimura, A. Miyoshi, and I. Shimada, eds. Asahi University, pp. 29-33, Gifu, Japan.

Turin, L., and A. E. Warner (1980) Intracellular pH in carly Xenopus embryos-Its effects on current flow between blastomeres. J. Physiol. (Lond.) 300: 489-504.

West, C. H. K., and R. A. Bernard (1978) Intracellular characteristics and responses of taste bud and lingual cells of the mudpuppy. J. Gen. Physiol. 72: 305-326.

White, R. L., D. C. Spray, A. C. Carvalho, and M. V. L. Bennett (1982) Voltage dependent gap junctional conductance between fish embryonic cells. Soc. Neurosci. Abstr. 8: 944. 